\title{
Analisis Strategi Pemasaran Kredit Pembiayaan Mitraguna Dalam Menarik Minat Nasabah Di Bank Syariah Indonesia Ex Bank Syariah Mandiri KCP Stabat
}

Ilvia Lanniza', Tuti Anggraini ${ }^{2}$

1,2 Universitas Islam Negeri Sumatera Utara

Corresponding Author : ilvialannizaaa@gmail.com

\section{ABSTRACT}

Pembiayaan Mitra Guna Berkah adalah layanan pembiayaan ragam kebutuhan atau multiguna dengan sumber pembayaran dari gaji atau pendapatan pegawai tetap. Banyaknya produk pembiayaan perbankan syariah yang ada di Indonesia mendorong perusahaan bersaing mendapatkan nasabah melalui berbagai strategi yang tepat. Penelitian bertujuan untuk untuk mengetahui dan menganalisis pengaruh strategi marketing mix dalam menarik minat nasabah terhadap pembiayaan kredit Mitra Guna Berkah. Dimensi marketing mix yang digunakan ada empat yaitu: Produk (Product), Tempat (Place), Harga (Price) dan Promosi (Promotion). Dengan menggunakan analisis deskriptif didapatkan hasil bahwa dari keempat dimensi marketing mix Promosi adalah yang paling dominan berpengaruh dalam menarik minat nasabah terhadap pembiayaan Mitra Guna Berkah.

Keywords

Pembiayaan Bank Syariah, Mitra Guna, Marketing Mix

\section{PENDAHULUAN}

Bank Syariah adalah lembaga keuangan yang usaha pokoknya memberikan pembiayaan dan jasa-jasa lainnya dalam lalu lintas pembayaran serta peredaran uang yang pengoperasiannya disesuaikan dengan prinsip syariat Islam. Di Indonesia bank syariah lahir sekitar tahun 90-an atau tepatnya setelah ada Undang-Undang No.7 Tahun 1992, yang direvisi dengan UndangUndang Perbankan No.10 Tahun 1998, dari peraturan perundang-undangan terseb ut dapat diketahui bahwa tujuan dikembangkan bank syariah adalah untuk memenuhi kebutuhan jasa perbankan bagi masyarakat yang tidak menerima konsep bunga. keberadaan bank syariah semakin mapan setelah diundangkannya Undang-Undang No. 21 Tahun 2008 tentang Perbankan Syariah.

Perbankan Islam didasarkan pada prinsip hukum Islam, berdasarkan adanya larangan dalam agama Islam untuk meminjamkan atau memungut pinjaman dengan mengenakan bunga pinjaman (riba), serta larangan untuk berinvestasi pada usaha-usaha berkategori terlarang (haram). Kegiatan operasional di dalam bank Islam menggunakan prinsip berdasarkan prinsip 
bagi hasil (mudharabah), pembiayaan berdasarkan prinsip usaha patungan (musyarakah), jual beli barang dengan memperoleh keuntungan (murabahah), atau pembiayaan barang modal berdasarkan prinsip sewa (ijarah). Perbankan Syariah tidak menggunakan sistem bunga sebagai alat untuk memperoleh pendapatan maupun membebankan bunga atas penggunaan dana pinjaman nasabah, karena riba di haramkan oleh syariah Islam.

Bank Syariah semakin berlomba- lomba setelah dikeluarkannya UndangUndang No. 21 Tahun 2008 dalam mengeluarkan produk-produk dan jasa-jasa yang sesuai dengan prinsip syariat Islam yang memberikan kemudahan, keuntungan serta kepuasan bagi nasabahnya, tentunya untuk memperkenalkan produk-produk yang ada di perbankan khususnya perbankan syariah adalah dengan cara memasarkan produk tersebut.

Seiring perkembangan perbankan yang semakin pesat, sebuah perencanaan merupakan hal pertama yang harus dilakukan dalam setiap aktivitas atau kegiatan yang dilakukan. Dengan adanya perencanaan yang disusun maka dengan mudah akan diketahui kemana arah usaha yang akan dijalankan, dan perencanaan berguna bagi tolak ukur kinerja suatu perusahaan apakah target yang di tetapkan berhasil dicapai atau tidak oleh perusahaan sehingga perusahaan dapat melakukan evaluasi terhadap strategi perusahaan. Strategi merupakan pendekatan secara keseluruhan yang berkaitan dengan pelaksanaan, kepuasan kondisional tentang tindakan yang akan dijalankan guna mencapai tujuan. Sedangkan perencanaan strategi adalah proses manajerial yang meliputi pengembangan dan pemeliharaan suatu keserasian yang berlangsung terus antara sasaran organisasi (perbankan) dan sumber daya dan berbagai peluang yang terdapat di dalamnya.

Dalam kamus istilah manajemen, strategi adalah rencana yang cermat mengenai kegiatan untuk mencapai sasaran secara khusus dan saling berhubungan dalam waktu dan ukuran. Dalam sebuah perusahaan, strategi merupakan salah satu faktor terpenting agar perusahaan dapat berjalan dengan baik. Strategi menggambarkan arah bisnis yang mengikuti lingkungan yang dipilih dan merupakan pedoman untuk mengalokasikan sumber daya usaha suatu organisasi (Fandy Tjiptono, 2002).

Perbankan sebagai penyedia jasa keuangan tentunya tidak bisa lepas dengan istilah pemasaran, guna menunjang pamasaran suatu perusahaan tentunya perlu adanya strategi pemasaran. Secara umum, pemasaran merupakan salah satu kegiatan pokok yang dilakukan oleh para pengusaha dalam usahanya untuk mempertahankan hidupnya untuk berkembang dan mendapatkan laba (Basu Swasta \& T. Handoko, 2000). Istilah pemasaran ditinjau dari proses sosial dapat didefenisikan sebagai suatu proses sosial dan 
melalui proses itu individu-individu dan kelompok memperoleh apa yang mereka butuhkan dan inginkan dengan cara menciptakan dan mempertukarkan produk dan nilai dengan individu dan kelompok lain (Philip Khotler, 1996).

Strategi pemasaran adalah memilih dan menganalisa pasar sasaran yang merupakan suatu kelompok orang yang ingin dicapai oleh perusahaan dan menciptakan suatu bauran pemasaran yang cocok dan yang dapat memuaskan pasar sasaran. Perusahaan perlu menetapkan strategi dasar atau disebut grand strategy atau strategi inti. Jika grand strategy ini sudah benar maka diharapkan perusahaan akan berhasil mencapai sasaran tesebut, diharapkan pasar akan menguasai market share yang luas ataupun market position yang mantap. Market share atau pangsa pasar artinya penguasaan luas pasar, sedangkan market position ialah kedudukan yang kokoh dari suatu produk pada suatu pasar.

Bank Syariah harus mampu memutuskan kegiatan strategi apa yang tepat bagi suatu produk yang dimiliki oleh perusahaan. Sebab setiap produk memiliki target pasar yang berbeda, sehingga pendekatan strategi yang dilakukan pun akan berbeda pula. Salah satunya adalah produk yang ditawarkan oleh Bank Syariah Indonesia Ex Bank Mandiri Syariah KCP Stabat yaitu produk pembiayaan atau financing.

Pembiayaan atau financing adalah penyedian uang atau tagihan yang dapat dipersamakan dengan itu, berdasarkan persetujuan atau kesepakatan antara bank dengan pihak lain yang mewajibkan pihak yang dibiayai untuk mengembalikan uang atau tagihan teresebut setelah jangka waktu tertentu dengan imbalan atau bagi hasil. Secara umum pembiayaan adalah suatu fasilitas yang diberikan oleh bank syariah kepada masyarakat yang membutuhkan untuk menggunakan dana yang telah dikumpulkan oleh bank syariah dari masyarakat yang surplus dana (Muhammad, 2000). Orientasi pembiayaan yang diberikan oleh Bank Syariah Mandiri adalah untuk meningkatkan dan mengembangkan nasabah Bank Syariah Mandiri dalam berbagai sektor, seperti hal nya adalah Produk Pembiayaan Implan.

Implan merupakan kata serapan dari Bahasa Inggris Implant secara bahasa berarti menanamkan atau memasukkan. Sedangkan dalam kamus ekonomi, Implant berarti memananamkan atau invest. Pembiayaan Implan adalah pemberian fasilitas pembiayaan konsumer kepada sejumlah pegawai (kolektif) dengan rekomendasi perusahaan atau instansi (approve company) dimana pembayaran angsurannya dikoordinasi oleh perusahaan atau instansi melalui pemotongan gaji langsung. Pengajuan-nya tersebut bisa dilakukan secara massal (kelompok) maupun secara individu atau perseorangan. Pembiayaan 
Implan dapat mengakomodir kebutuhan pembiayaan bagi para karyawan perusahaan. Pembiayaan Implan digunakan oleh pengguna dana untuk memenuhi kebutuhan yang sifatnyakonsumtif dan akan habis dalam memenuhi kebutuhannya.

Strategi pemasaran yang dilakukan oleh Bank Syariah Indonesia Ex Bank Mandiri Syariah secara terpadu sebagai usaha untuk memuaskan keinginan nasabah. Secara umum strategi pemasaran yang dilakukan adalah dengan menerapkan Marketing Mix (bauran pemasaran), Kotler dan Keller menyatakan bahwa bauran pemasaran adalah sekumpulan alat pemasaran yang dapat digunakan oleh perusahaan untuk mencapai tujuan pemasarannya. Bauran pemasaran terdiri dari Product (produk), Price (harga), Place (tempat), dan Promotion (promosi). Produk adalah titik sentral dari kegiatan marketing, semua kegiatan marketing lainnya digunakan untuk menunjang pamasaran produk. Pada setiap produk atau jasa yang ditawarkan, bagian pemasaran dapat menentukan harga pokok dan harga jual suatu prod uk. Faktor-faktor yang perlu dipertimbangkan dalam suatu penetapan harga antara lain biaya, keuntungan, harga yang ditetapkan oleh pesaing, dan perubahan keinginan pasar, oleh karena itu harga sangat penting dalam sistem pemasaran perusahaan. Selain itu promosi merupakan komponen yang dipakai dalam bauran pemasaran untuk memberitahukan dan mempengaruhi pasar bagi produk perusahaan, sehingga pasar dapat mengetahui tentang produk yang diproduksi oleh perusahaan tersebut.

\section{METODE PENELITIAN}

Dalam penelitian ini, menggunakan jenis penelitian kualitatif dengan metode deskriptif. Data-data dikumpulkan, disusun, dikelompokkan, dianalisis, kemudian di integrasikan sehingga menjadi gambaran yang jelas dan terarah mengenai masalah yang diteliti. Merupakan metode penelitian yang dilakukan degan cara langsung terjun ke objek penelitian yang diteliti pada Bank Syariah Indonesia Ex Bank Mandiri Syariah Kantor Cabang Pembantu Stabat.

Metode Pengumpulan data adalah Pengamatan (observasi), yakni melakukan pengamatan secara langsung pada objek yang diteliti dan Wawancara (interview), yakni melakukan tanya jawab dengan pihak-pihak yang berwenang dalam perusahaan tersebut untuk memperoleh keterangan yang berkaitan dengan penelitian. Adapun sumber data dilakukan dengan Data Primer adalah Data yang diperoleh secara langsung oleh penulis dari responden atau tempat penelitian yang dijadikan objek dari penelitian dan Data Sekunder adalah Data yang diperoleh melalui buku-buku atau 
literatur-literatur yang ada hubungannya dengan masalah yang diteliti. Data ini berupa landasan teori atau pedoman-pedoman lain yang berhubungan dengan permasalahan yang diteliti.

Teknik pengumpulan data adalah Penelitian terhadap suatu fenomena dapat dilakukan pada lingkungan yang natural maupun lingkungan buatan (artificial). Lingkungan studi penelitian ini adalah lingkungan natural, berupa studi lapangan (field study) yakni dengan mengambil informasi dari objek penelitian yaitu PT. Bank Syariah Indonesia Ex Bank Mandiri Syariah kantor cabang pembantu Stabat.

Metode analisis data yang digunakan dalam penelitian ini adalah metode dalam bentuk deskriptif, dimana tujuannya dalam penelitian ini adalah untuk memberikan gambaran mengenai penelitian penulis tentang strategi yang diterapkan dalam menarik minat nasabah menggunakan pembiayaan kredit mitra pada PT. Bank Syariah Indonesia Ex Bank Mandiri Syariah kantor cabang pembantu Stabat.

\section{HASIL DAN PEMBAHASAN}

Indonesia sebagai Negara dengan penduduk muslim terbesar di dunia, memiliki potensi untuk menjadi yang terdepan dalam industri keuangan Syariah. Meningkatnya kesadaran masyarakat terhadap halal matter serta dukungan stakeholder yang kuat, merupakan factor penting dalam pengembangan ekosistem industri halal di Indonesia. Termasuk di dalamnya adalah Bank Syariah. Bank Syariah memainkan peranan penting sebagai fasilitator pada seluruh aktivitas ekonomi dalam ekosistem industry halal. Keberadaan industry perbankan Syariah di Indonesia sendiri telah mengalami peningkatan dan pengembangan yang signifikan dalam kurun tiga decade ini. Inovasi produk, peningkatan layanan, serta pengembangan jaringan menunjukkan trend yang positif dari tahun ke tahun. Bahkan, semangat untuk melakukan percepatan juga tercermin dari banyaknya Bank Syariah yang melakukan aksi korporasi. Tidak terkecuali dengan Bank Syariah yang dimiliki Bank BUMN, yaitu Bank Syariah Mandiri, BNI Syariah, dan BRI Syariah.

Pada 1 Februari 2021 yang bertepatan dengan 19 Jumadil Akhir $1442 \mathrm{H}$ menjadi penanda sejarah bergabungnya Bank Syariah Mandiri, BNI Syariah, dan BRI Syariah menjadi satu entitas yaitu Bank Syariah Indonesia (BSI). Penggabungan ini akan menyatukan kelebihan dari ketiga Bank Syariah sehingga menghadirkan layanan yanglebih lengkap, jangkauan yang lebih luas, serta memiliki kapasitas permodalan yang jauh lebih baik. Didukung sinergi dengan perusahaan induk (Mandiri, BNI, BRI) serta komitmen pemerintah melalui Kementerian BUMN, Bank Syariah Indo nesia 
didorong untuk dapat bersaing di tingkat global. Penggabungan ketiga Bank Syariah tersebut merupakan ikhtiar untuk melahirkan Bank Syariah kebanggan umat, yang diharapkan menjadi energi baru pembangunan ekonomi nasional serta berkontribusi terhadap kesejahteraan masyarakat luas. Keberadaan Bank Syariah Indonesia juga menjadi cerminan wajah perbankan Syariah di Indonesia yang modern, universal, dan memberikan kebaikan bagi segenap alam (Rahmatan Lil"eAalamiin).

\section{Pengertian Marketing Mix}

Setiap perusahaan harus memutuskan sejauh mana menyesuikan strategi pemasarannya dengan kondisi-kondisi yang ada. Pada sisi yang satu terdapat perusahaan-perusahaan yang menggunakan marketing mix yang terstandarisasi secara global di seluruh dunia. Standarisasi tersebut adalah produk, iklan, distribusi dan biaya rendah. Pada sisi lainnya terdapat penyesuaian pada marketing mix, dimana produsen tersebut menyesuikan elemen-elemen marketing mix untuk masing "Bauran pemasaran adalah variabel- variabel yang dapat dikendalikan oleh perusahaan, yang terdiri dari produk, harga, distribusi, dan promosi".

Pengertian marketing mix menurut beberapa ahli diantaranya:

1. Kotler Armstrong (1997), pengertian marketing mix menurut Kotler adalah perangkat pemasaran yang taktis dan dapat dikendalikan perusahaan. Unsur di dalamnya meliputi 4P yaitu produk, harga, tempat distribusi, dan promosi yang kemudian dipadukan oleh perusahaan untuk mencapai target market yang diinginkan.

2. Soemarni dan Soeprihanto (2010), marketing mix adalah kombinasi variabel inti sistem pemasaran yang terdiri dari produk, harga, promosi, dan distribusi oleh perusahaan guna mempengaruhi tanggapan konsumen.

3. Buchari Alma (2005), marketing mix adalah sebuah strategi dalam mengkombinasikan berbagai kegiatan pemasaran demi memaksimalkan hasil yang bisa diterima.

Berdasarkan definisi di atas dapat diambil kesimpulan pengertian dari marketing mix adalah dimensi-dimensi yang dikuasai dan dapat digunakan oleh marketing manajer guna mempengaruhi penjualan atau bisa juga diartikan sebagai pendapatan perusahaan.

\section{Dimensi-Dimensi Marketing Mix}

Strategi Pemasaran yang diterapkan Bank Syariah Indonesia KCP Stabat pada pembiayaan Mitraguna menggunakan strategi bauran pemasaran yakni sebagai berikut : 


\section{Produk (Product)}

Produk merupakan segala sesuatu yang dapat ditawarkan produsen untuk diperhatikan, diminta, dicari, dibeli, digunakan, atau dikonsumsi pasar sebagai pemenuhan kebutuhan atau keinginan pasar bersangkutan, baik berupa barang maupun jasa (Kotler \& Amstrong, 2006). Produk adalah barang atau jasa yang dihasilkan untuk digunakan oleh konsumen guna memenuhi kebutuhannya dan memberikan kepuasan (Sofjan Assauri, 2007).

Pembiayaan Mitraguna adalah pemberian fasilitas pembiayaan konsumer kepada sejumlah pegawai (kolektif) dengan rekomendasi perusahaan atau instansi (approve company) dimana pembayaran angsurannya dikoordinasi oleh perusahaan atau instansi melalui pemotongan gaji langsung. Pengajuannya tersebut bisa dilakukan secara massal (kelompok) maupun secara individu (perorangan). Pembiayaan Mitraguna dapat mengakomodir kebutuhan pembiayaan bagi para karyawan perusahaan. Pembiayaan Mitraguna menurut Ibu Nia selaku Branch Manager merupakan Produk unggulan dari Bank Syariah Indonesia KCP Stabat yang memiliki target pasar yaitu Pegawai Negeri Sipil seperti Pendidik, Kemenag dan Dinas Kesehatan Fokusnya pada seluruh instansi yang penyaluran gajinya melalui KPPN dan BUMN serta Bank Syariah Indonesia KCP Stabat telah menjalin kerjasama dengan beberapa Intansi yaitu Kemenag Kota Stabat, MTSN 1 Stabat, MAN 1 Langkat, MAN 3 Stabat, BPJS Kota Stabat dll.

Adapun produk pembiayaan Mitraguna tersebut memiliki kelebihan sebagai berikut:

a. Angsuran yang bersifat tetap dan tidak berubah sampai lunas.

b. Bisa melakukan take over dari bank lain.

c. Jangka waktu yang diberikan oleh Bank Syariah Indonesia maksimal 15 tahun, dan tidak semua bank bisa memberikan jangka waktu selama itu, biasanya rata-rata hanya memberi waktu maksimal 12 tahun.

d. Pembiayaan mitraguna terd iri dari pembiayaan dengan payroll dan non payroll.Pada payroll aset dari gaji sebesar $70 \%$, sedangkan non payroll sebesar $50 \%$, danbiasanya bank lain rata-rata sebesar $40 \%$.

e. Jaminan untuk pengajuan pembiayaan mitraguna ini hanya memberikan SK asli PNS/CPNS. Untuk meningkatkan pertumbuhan produk Bank Syariah Indonesia KCP Stabat dapat secara agresif menekankan kelebihan-kelebihan dari produk pembiayaan mitraguna tersebut kepada calon nasabah.

2. Harga (Price)

Harga adalah sejumlah uang yang dibutuhkan untuk memperoleh 
beberapa kombinasi sebuah produk dan pelayanan yang menyertainya (Angiopora P Marius, 1999). Strategi harga sangat berperan dalam meningkatkan pertumbuhan dari produk pembiayaan Mitra Guna pada Bank Syariah Indonesia KCP Stabat. Strategi harga disini berkaitan dengan tingkat margin yang ditentukan perusahaan. Margin pun dapat digunakan untuk menciptakan strategi pemasaran yang agresif. Yakni margin Bank Syariah Indonesia KCP Stabat memiliki nilai bersaing margin sejenis dari bank lain. Bank Syariah Indonesia KCP Stabat menetapkan Margin yang kompetitif, dan plafond pembiayaan Mitraguna mulai dari 5 juta hingga 500 juta dengan tingkat margin $11,5 \%$, dengan jangka waktu pembiayaan mitra guna 5-15 tahun, jumlah pembiayaan juga dapat disesuaikan dengan gaji nasabah yang diperoleh dalam setiap bulannya sehingga angsuran tidak memberatkan nasabah. Dengan margin yang cukup rendah serta angsuran yang tetap menjadi keunggulan Bank Syariah Indonesia KCP Stabat untuk menarik minat nasabah.

3. Tempat (Place)

Produk industri place diartikan sebagai saluran distribusi, sedangkan untuk produksi jasa place diartikan sebagai tempat pelaayanan jasa (Hurriyati, 2005). Penentuan lokasi daerah kantor merupakan salah satu kebijakan yang sangat penting dalam meningkatkan pertumbuhan produk pembiayaan Mitraguna dari Bank Syariah Indonesia KCP Stabat. Lokasi yang strategis dapat mempermudah nasabah dalam bertransaksi dengan Bank. Bank Syariah Indonesia KCP Stabat berlokasi di Jl. K. H. Zainul Arifin No. 17 A Stabat, Sumatera Utara. Keunggulan dari lokasi tersebut adalah:

a. Kantor Bank Syariah Indonesia KCP Stabat terletak di jalan K.H. Zainul Arifin No. 17 A, Kota Stabat merupakan jalan lintas Medan Aceh yang paling sering digunakan oleh pengguna kendaraan karena berada dipusat kota Stabat, sehingga akses nya mudah dijangkau oleh masyarakat luas dengan berbagai sarana transportasi.

b. Lokasi yang sangat strategis dikarenakan dekat dengan pusat perbelanjaan supermarket, dan juga dekat dengan perumahan masyarakat.

c. Area Parkir yang memadai dan nyaman memudahkan akses bagi nasabah

baik menggunakan kendaraan roda dua ataupun roda empat.

d. Bentuk fisik Bangunan yang luas terdiri dari dua lantai, serta bersih dan tentunya dilengkapi dengan fasilitas yang modern, baik ATM, AC, Camera CCTV, dan komputerisasi. Bank Syariah Indonesia KCP Stabat 
memiliki tempat yang sangat strategis dan mempunyai fasilitas yang begitu lengkap dan nyaman sehingga hal tersebut sangat menunjang bagi perbankan, serta dapat menarik calon nasabah serta dapat berpengaruh terhadap peningkatan pertumbuhan produk Bank Syariah Indonesia KCP Stabat.

\section{Promosi (Promotion)}

Pada hakikatnya promosi adalah suatu bentuk komunikasi pemasaran, yang dimaksud dengan komunikasi pemasaran adalah aktivitas pemasaran yang berusaha menyebarkan informasi, mempengaruhi dan mengingatkan pasar sasaran atas perusahaan dan produknya agar bersedia menerima, membeli dan loyal pada produk yang ditawarkan perusahaan yang bersangkutan (Tjiptono, 2005). Promosi merupakan strategi pemasaran yang bertujuan untuk memperkenalkan produk ke masyarakat. Untuk memaksimalkan pertumbuhan suatu produk, Bank Syariah menggunakan salah satu aspek pemasaran yaitu promosi. Promosi yang dilakukan oleh Bank Syariah Indonesia KCP Stabat, adalah sebagai berikut:

a. Sosialisasi ke seluruh instansi yang ada di kota Stabat.

b. Melakukan gathering atau pertemuan.

c. Membagikan brosur produk pembiayaan Mitra Guna

d. Bank Syariah Indonesia KCP Stabat bekerjasama dengan bendahara dan pimpinan Intansi, serta memberikan fee atau biasa disebut dengan dana Maintenance.

Bank Syariah Indonesia KCP Stabat memberikan sponsorsif kepada instansi yang bekerja sama dengan Bank Syariah Indonesia KCP Stabat, seperti membantu memeriahkan acara yang diadakan oleh instansi. Berdasarkan wawancara dengan Ibu Nia selaku Branch Manager Bank Syariah Indonesia KCP Stabat strategi yang digunakan dalam menjalin kerjasama dengan instansi- intansi yang telah bekerja sama dengan Bank Syariah Indonesia KCP Stabat adalah dengan memperkenalkan produk pembiayaan mitraguna tersebut kepada calon intansi yang akan bekerja sama, selain itu juga terdapat lobi atau pun komunikasi yang dijalin antara Bank Syariah Indonesia KCP Stabat de ngan pimpinan atau bendahara perusahaan ataupun intansi yang akan menjalin kerja sama.

\section{KESIMPULAN}

Setelah melakukan pembahasan dalam penulisan ini, berdasarkan analisis baik secara teoritis maupun kesimpulan berdasarkan praktik di lapangan, maka penulis mengambil beberapa kesimpulan, yaitu: Keberhasilan Strategi pemasaran Produk Pembiayaan Mitraguna yang 
Journal Economy And Currency Study (JECS)

Volume 3, Issue 2, July 2021

Page 37-46

dilakukan oleh Bank Syariah Indonesia KCP Stabat adalah dari segi promosi yang dilakukan sehingga dalam setiap tahunnya untuk produk pembiayaan Mitra guna selalu mengalami peningkatan, promosi yang dilakukan adalah sebagai berikut:

1. Sosialisasi ke seluruh instansi yang ada di kota Stabat.

2. Melakukan gathering atau pertemuan (Silaturahmi)

3. Membagikan brosur produk pembiayaan Mitraguna

4. Bank Syariah Indonesia bekerjasama dengan bendahara dan pimpinan Intansi, serta memberikan fee atau biasa disebut dengan dana Maintenance.

5. Bank Syariah Indonesia KCP Stabat memberikan sponsorsif kepada instansi yang bekerja sama dengan Bank Syariah Indonesia KCP Stabat, seperti membantu memeriahkan acara yang diadakan oleh instansi.

Adapun saran dalam penelitian ini adalah sebaiknya Bank Syariah Indonesia KCP Stabat dapat lebih agresif lagi dalam melakukan kerjasama dengan intansi- intansi sehingga dapat lebih meningkatkat jumlah nasabah pembiyaan Mitraguna, Serta Bank Syariah Indonesia KCP Stabat harus membangun hubungan lebih baik lagi dengan para nasabah Pembiayaan Mitraguna bukan hanya kepada Pimpinan dan Bendahara intansi-intansi yang melakukan kerjasama dengan Bank Syariah Indonesia KCP Stabat.

\section{DAFTAR PUSTAKA}

Angiopora P Marius. Dasar-Dasar Pemasaran. Jakarta: PT. Raja Grafindo, 1999.

Basu Swasta dan T. Handoko. Manajemen Pemasaran. Yogyakarta: BPFE, 2000.

Fandy Tjiptono. Strategi Pemasaran. Yogyakarta: Andi, 2002.

Hurriyati. Bauran Pemasaran \& Loyalitas Konsumen. Bandung: Alfabeta, 2005.

Kotler dan Amstrong. Dasar-dasar Pemasaran Jilid dua. Jakarta: PT. INDEKS, 2006.

Kotler, P. Marketing Jilid 1 Edisi Bahasa Indonesia dari Marketing Essentials. Jakarta: Erlangga. 1997.

Muhammad. Bank dan Lembaga Umat Kontemporer. Yogyakarta: UII Press, 2000.

Philip Khotler. Marketing Manajemen: Analisis, Planning, Implementasi dan Kontrol, Terj. Hendra Teguh. Jakarta: Erlangga, 1996.

Sofjan Assauri. Manajemen Pemasaran (Dasar, Konsep, dan Strategi). Jakarta: PT. Raja Grafindo Persada, 2007.

Tjiptono, F. Pemasaran Strategik. Yogyakarta: Andi, 2005. 